\title{
EVALUASI PENERAPAN SISTEM SPESIFIKASI UMUM 2010 (REVISI 3) PADA PELAKSANAAN PROYEK JALAN DI KABUPATEN GIANYAR
}

\author{
Nyoman Martha Jaya ${ }^{1}$, G.A.P. Candra Dharmayanti², I Nyoman Dinton Vicky \\ Budi Laksana ${ }^{3}$ \\ ${ }^{1,2,3}$ Program Magister Teknik Sipil, Universitas Udayana, Denpasar \\ Email : dinton.vicky@gmail.com
}

doi: https://doi.org/10.24843/SPEKTRAN.2021.v09.i01.p08

\begin{abstract}
ABSTRAK
Pembangunan proyek jalan masih banyak mengalami kendala penerapan spesifikasi umum 2010 (revisi 3) oleh penyedia jasa, hasil yang diharapkan tidak sesuai dengan mutu pekerjaan yang di isyaratkan. Penelitian ini bertujuan mengevaluasi terhadap hasil pekerjaan dengan mengetahui penyimpangan dan kegagalan kontraktor untuk memenuhi ketentuan spesifikasi pada divisi 3 sampai dengan divisi 7 yang sering mengalami ketidak sesuaian pada spesifikasi umum 2010. Metode pada penelitian ini menggunakana survey dan kuesioner. Responden dipilih berdasarkan purvosive sampling kemudian dianalisa dengan metode sebab akibat (fishbone Analysis) dan Root Cause Analysis (RCA). pekerjaan yang mengalami kendala ketidasuaian didominasi pekerjaan galian lapis pondasi agregat $(95,83 \%)$ diikuti dengan pekerjaan galian dan campuran beraspal panas $(83,33 \%)$, pasangan batu $(75 \%)$, pekerjaan pelebaran dan perkerasan $(70,83 \%)$. Kendala yang terjadi karena kurang tegasnya team dari kotraktor untuk melakukan metode pekerjaan, kordinasi kepada masyarakat yang membutuhkan waktu lama, kurangnya pengawasan di base camp dan membeli dari supplier yang membuat campuran berbeda saat bahan sampai di lokasi proyek. Upaya pencegahan yang dilakukan yaitu kontraktor agar bekerja sesuai spesifikasi dan metode kerja untuk mencapai mutu, harus di lakukan kordinasi dan kesepakatan antara PDAM, Desa, dan kontraktor sebelum di lakukan galian, apabila terkena galian tidak meminta ganti rugi, pemilihan bahan harus tepat, dan peningkatan quality control di quarry, baik untuk material, komposisi untuk mencapai spesifikasi yang diminta (PI, CBR, abrasi, ukuran butir), kordinasi atau bersurat, melakukan sosialisasi dan membuat kesepakatan kerja sama.
\end{abstract}

Kata kunci: Spesifikasi Umum 2010 (revisi 3), Kendala Pekerjaan, Penerepan, Upaya Pencegahan.

\section{THE EVALUATION OF APPLICATION OF THE 2010 GENERAL SPECIFICATION SYSTEM (REVISION 3) ON IMPLEMENTATION OF THE ROAD PROJECT IN GIANYAR REGENCY}

\begin{abstract}
The construction of road projects still faces many obstacles in the application of the 2010 general specifications (revision 3) by service providers, the expected results are not in accordance with the quality of work required. This study aims to evaluate the work results by knowing the deviations and failures of the contractor to meet the specifications in divisions 3 to 7 , which often experience non-conformities in general specifications 2010. The method in this study uses a survey and a questionnaire. Respondents were selected based on purposive sampling then analyzed using the fishbone analysis and root cause analysis (RCA) methods. jobs that experience failure constraints are dominated by aggregate foundation layer excavation work $(95.83 \%)$ followed by excavation work and hot asphalt mixture $(83.33 \%)$, masonry $(75 \%)$, widening and pavement work (70.83\%). The obstacles that occurred were due to the lack of firmness in the contractor team to carry out the work method, coordination to the community which took a long time, lack of supervision at the base camp and buying from suppliers who made different mixtures when the materials arrived at the project site. Preventive efforts are made, namely the contractor to work according to specifications and work methods to achieve quality, coordination and agreement must be made between the PDAM, the village, and the contractor before excavation is carried out, if the excavation is affected, do not ask for compensation, the selection of materials must be appropriate, and increase quality control in quarry, both for material, composition to achieve the required specifications (PI, CBR, abrasion, grain size), coordination or writing, socializing and making cooperation agreements.
\end{abstract}

Key words: General Specifications (revision 3), Work Constraints, Implementation, Prevention Efforts. 


\section{PENDAHULUAN}

Pembangunan proyek jalan masih banyak mengalami kendala penerapan spesifikasi umum 2010 (revisi 3) oleh Penyedia Jasa, hasil yang diharapkan tidak sesuai dengan mutu pekerjaan yang di isyaratkan. Spesifikasi ini bertujuan untuk mencapai suatu produk pekerjaan mulai dari proses persiapan, metode pelaksanaan, bahan, peralatan, pengendalian mutu, dan tata cara pembayaran, Kegunaan dari spesifikasi ini adalah tentang Penyampaian Standar Dokumen Pengadaan dan Spesifikasi Umum 2010 (Revisi 3) untuk pekerjaan konstruksi jalan dan jembatan dalam mencapai kualitas dan mutu. Dokumen spesifikasi umum pekerjaan kontruksi jalan dan jembatan, merupakan bagian dari dokumen kontrak pekerjaan kontruksi jalan dan jembatan yang bertujuan untuk mencapai kualitas standar suatu produk pekerjaan mulai dari proses persiapan, metode pelaksanaa, bahan, peralatan, pengendalian mutu, dan tata cara pembayaran. Penerapan spesifikasi ini dilakukan selama periode pelaksanaan pekerjaan kontruksi sebagai dasar penentuan pembayaran anatara penyedia jasa dengan Dinas Pekerjaan Umum. Hal ini diperkuat dengan fakta yang dimuat (Indonesiakoran.com, 2017). Tentang pengerjaan proyek pengaspalan ruas jalan Petulu Gunung - Junjungan - Duur Beringin berlokasi di Kabupaten Gianyar dikerjakan tidak sesuai spesifikasi yang di syaratkan, dibeberapa titik ditemukan ada galian yang belum dipadatkan justru sudah ditutup atau ditimbun dengan agregat. Dinas terkait serta konsultan pengawas, agar tidak membiarkan hal semacam ini terjadi dilapangan, yang berpangaruh terhadap mutu pekerjaan dan pengembalian dana. Permasalahan terkait ketidak seuaian hasil pekerjan dengan spesifikasi umum 2010 (revisi 3) perlu dilakukan evaluasi terhadap hasil pekerjaan dengan mengetahui penyimpangan-peyimpangan dan kegagalan kontraktor untuk memenuhi ketentuan spesifikasi pada divisi 3 sampai dengan divisi 7 yang sering mengalami ketidak sesuaian pada spesifikasi umum 2010 ( B.P, Wawancara, 2018).

\section{SPESIFIKASI UMUM 2010 (REVISI 3)}

\subsection{Tujuan dan Kegunaan Spesifikasi Umum 2010 (revisi 3)}

Dokumen spesifikasi umum pekerjaan konstruksi jalan dan jembatan ini merupakan bagian dari dokumen kontrak pekerjaan konstruksi jalan dan jembatan yang bertujuan untuk mencapai suatu produk pekerjaan mulai dari proses persiapan, metode pelaksanaan, bahan, peralatan, pengendalian mutu, dan tata cara pembayaran. Penerapan spesifikasi ini dilakukan selama periode pelaksanaan pekerjaan konstruksi sebagai dasar penentuan pembayaran.

Spesifikasi Umum ini berlaku sejak 12 November 2014 sejak dikeluarkannya Surat Edaran Direktur Jenderal Bina Marga Nomor 10/SE/Db/2014. Kegunaan dari spesifikasi ini adalah tentang Penyampaian Standar Dokumen Pengadaan dan Spesifikasi Umum 2010 (Revisi 3) untuk Pekerjaan Konstruksi Jalan dan Jembatan dalam mencapai kualitas dan mutu sehingga dapat mempermudah implementasi spesifikasi umum tersebut dalam pelaksanaan pekerjaan jalan (Soelistijo, 2018)

Dalam spesifikasi umum ini terdapat 10 divisi yang terbagi atas jenis pekerjaan yang dilakukan. Divisi tersebut terbagi menjadi umum, drainase, pekerjaan tanah, pelebaran perkerasan dan bahu jalan, perkerasan berbutir dan perkerasan beton semen, perkerasan aspal, struktur, pengembalian kondisi dan pekerjaan minor, pekerjaan harian, dan pekerjaan pemeliharaan rutin, sedangkan pada masing-masing item pekerjaan ada penjelasan mengenai pengertian umum, bahan, pelaksanaan, pengukuran dan pembayaran. Masing-masing divisi dibagi menjadi beberapa seksi sesuai dengan spesifikasi pekerjaan yang ada pada divisi tersebut.

a. Divisi 1 Umum

Divisi 1 terdiri atas ringkasan pekerjaan, mobilisasi, kantor lapangan dan fasilitasnya, fasilitas dan pelayanan pengujian, transportasi dan penanganan, pembayaran sertifikat bulanan, pembayaran sementara (provisional sums), manajemen dan keselamatan lalulintas, kajian teknis lapangan, standar rujukan, bahan dan penyimpanan, jadwal pelaksanaan, prosedur perintah perubahan, penutupan kontrak, dokumen rekaman kegiatan, pekerjaan pembersihan, pengamanan lingkungan hidup, relokasi utilitas dan pelayanan yang ada, keselamatan dan kesehatan kerja, pengujian pengeboran, dan manajemen mutu.

b. Divisi 2 Drainase

Divisi 2 terdiri atas selokan dan saluran air, pasangan batu dengan mortar, gorong-gorong dan drainase beton, dan drainase porous.

c. Divisi 3 Pekerjaan Tanah

Divisi 3 terdiri atas galian, timbunan, penyiapan badan jalan, pembersihan, pengupasan, dan pemotongan pohon, dan geotekstil.

d. Divisi 4 Pelebaran Perkerasan dan Bahu Jalan

Divisi 4 terdiri atas pekerjaan pelebaran perkerasan dan pekerjaan bahu jalan. 
e. Divisi 5 Perkerasan Berbutir dan Perkerasan Beton Semen

Divisi 5 terdiri atas lapis pondasi agregat, perkerasan berbutir tanpa penutup aspal, pekerasan beton semen, lapis pondasi semen tanah, lapis pondasi agregat semen.

f. Divisi 6 Perkerasan Aspal

Divisi 6 terdiri atas lapis resap pengikat dan lapis perekat, laburan aspal satu lapis (burtu) dan laburan aspal dua lapis (burda), campuran beraspal panas, lasbutag dan latasbutir, campuran aspal dingin, lapis penetrasi macadam, dan pemeliharaan dengan laburan aspal.

g. Divisi 7 Struktur

Divisi 7 terdiri atas beton, beton pratekan, baja tulangan, baja struktur, pemasangan jembatan baja standar, pondasi tiang, pondasi sumuran, adukan semen, pasangan batu, pasangan batu kosong dan bronjong, sambungan ekspansi (expansion joint), perletakan (bearing), sandaran (railing), papan nama jembatan, pembongkaran struktur, drainase lantai jembatan.

h. Divisi 8 Pengembalian Kondisi dan Pekerjaan Minor

Divisi 8 terdiri atas pengembalian kondisi perkerasan lama, pengembalian kondisi bahu jalan lama pada perkerasan berpenutup aspal, pengembalian kondisi selokan, saluran air, galian, timbunan dan penghijauan, perlengkapan jalan dan pengatur lalulintas, dan pengembalian kondisi jembatan.

i. Divisi 9 Pekerjaan Harian

Divisi 9 terdiri atas pekerjaan harian, dan

j. Divisi 10 Pekerjaan Pemeliharaan Rutin

Divisi 10 terdiri atas pemeliharaan rutin perkerasan, bahu jalan, drainase, perlengkapan jalan dan jembatan, serta pemeliharaan jalan samping dan jembatan.

Implementasi Spesifikasi Umum 2010 Revisi 3 menghadapi beberapa kendala di lapangan. Kualitas pekerjaan pembangunan jalan seringkali tidak memenuhi harapan. Hal ini disebabkan karena kurangnya pemahaman penyedia jasa pada spesifikasi umum dan seringkali penyedia jasa kehilangan orientasi terhadap urutan kegiatan pelaksanaan suatu pekerjaan. Kajian ini dilakukan untuk mendukung implementasi Surat Edaran Direktur Jenderal Bina Marga No. 10/SE/Db/2014 sehingga dapat mempermudah implementasi spesifikasi umum tersebut dalam pelaksanaan pekerjaan jalan (Soelistijo,2018).

\subsection{Pengumpulan Data}

Mengingat keterbatasan tenaga dan waktu, penulis menggunakan sampel dalam pelaksanaan penelitian. Menurut (Sugiarto et al., 2003) sampel adalah sebagian anggota dari populasi yang dipilih dengan menggunakan prosedur tertentu sehingga dapat mewakili populasinya, dimana populasi adalah keseluruhan unit atau individu dalam ruang lingkup yang ingin diteliti. Penelitian lapangan bertujuan untuk memperoleh jawaban penegasan setuju atau tidak setuju responden terhadap pernyataan data kuesioner yang dibagikan (Proboyo, 1999)

Teknik pengambilan data sampel adalah suatu usaha untuk memperoleh data yang mewakili populasi pengamatan. Teknik pengambilan sampel dapat dibagi menjadi 2 yaitu: (Armando, 2013)

1. Probability sampling: pemilihan sampel secara random serta memberikan kesempatan yang sama bagi anggota dalam populasi.

a. Sampling acak: memberikan kesempatan secara acak bagi semua anggota dalam populasi sebagai sampel.

b. Teknik stratifikasi : sampel memiliki karakteristik yang berbeda dari beberapa lapisan, kelompok individu populasi yang ada.

c. Teknik Klaster: sampel yang dipilih berdasarkan kelompok, daerah atau kelompok subjek yang berkumpul bersama-sama.

d. Teknik secara sistematis : sampel menggunakan prinsip proporsional.

2. Non probability sampling : pemilihan sampel yang dibatasi dengan tidak memberi peluang yang sama pada popolasinya.

a. Sampling sistematis: sampel dipilih berdasarkan nomor urut.

b. Sampling kuota : sampel ditentukan dengan ciri-ciri dan jumlah kuota yang diinginkan.

c. Sampling insidental : sampel dapat diambil dari setiap sumber yang kebetulan bertemu dengan peneliti, sampel tersebut bagian dari sumber data yang diinginkan.

d. Purposive sampling : penentuan sampel dengan pertimbangan tertentu memiliki tujuan yang jelas sampelnya.

e. Sampling jenuh: semua anggota dalam populasi dipergunakan sebagai sampel. 
f. Snowball sampling : jumlah sampel bisa berkembang lebih banyak dari rencana semula, karena kebutuhan data yang belum lengkap.

\subsection{Fishbone Diagram}

(Ilie \& Ciocoiu, 2010) mendefinisikan diagram Fishbone sebagai alat (tool) yang menggambarkan sebuah cara yang sistematis dalam memandang berbagai dampak atau akibat dan penyebab yang membuat atau berkontribusi dalam berbagai dampak tersebut. Oleh karena fungsinya tersebut, diagram ini biasa disebut dengan diagram sebab-akibat.

\section{Fishbone Diagram}

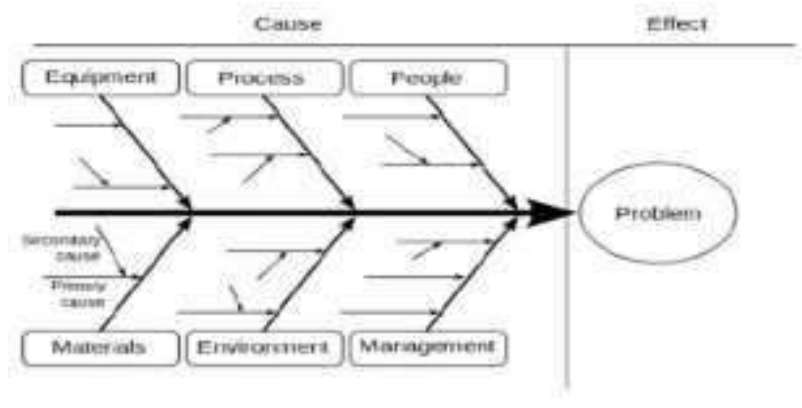

Gambar 1. Fishbone diagram

Diagram Fishbone (Ishikawa) pada dasarnya menggambarkan sebuah model sugestif dari hubungan antara sebuah kejadian (dampak) dan berbagai penyebab kejadiannya. Struktur dari diagram tersebut membantu para pengguna untuk berpikir secara sistematis (Ilie \& Ciocoiu, 2010). Fishbone Diagrams adalah alat analisis yang menyediakan cara sistematis melihat efek dan penyebab yang membuat atau berkontribusi terhadap efek tersebut. Karena fungsi diagram Fishbone, dapat disebut sebagai diagram sebab-akibat (Ilie \& Ciocoiu, 2010)

\subsection{Root Cause Analysis (RCA)}

Root Cause Analysis (RCA) merupakan pendekatan terstruktur untuk mengidentifikasi factor-faktor berpengaruh pada suatu atau lebih kejadian-kejadian yang lalu agar dapat digunakan untuk meningkatkan kinerja (Corcoran \& Wals, 2004). Selain itu pemanfaatan RCA dalam analisis perbaikan kinerja menurut (Latino et al., 2019)dapat memudahkan pelacakan terhadap faktor yang mempengaruhi kinerja Root Cause adalah bagian dari beberapa faktor (kejadian, kondisi, faktor organisasional) yang memberikan kontribusi atau menimbulkan kemungkinan penyebab dan diikuti oleh akibat yang tidak diharapkan. Tempat berbagai metode evaluasi terstruktur untuk mengidentifikasi akar penyebab (root cause) suatu kejadian yang tidak diharapkan (undesired outcome) (Gao et al., 2008)

\section{KERANGKA DAN KONSEP}

\subsection{Kerangka Berfikir}

Pada pembangunan proyek-proyek jalan penerapan aturan dan Spesifikasi Umum 2010 (revisi 3) masih banyak mengalami kendala penerapan oleh Penyedia Jasa. Penelitian ini dilakukan dengan tujuan akhirnya adalah menganalisis pekerjaan yang mengalami kendala penerapan spesifikasi di lapangan pada divisi 3 sampai divisi 7, untuk mengevaluasi kendala terhadap penerapan aturan Spesifikasi Umum 2010 (revisi 3) dan merumuskan upaya untuk mencegah tidak tercapainya kualitas pada spesifikasi umum 2010 (revisi 3) pada pelaksanaan proyek jalan di Kabupaten Gianyar.

Penelitian tentang evaluasi kendala dalam penerapan sistem spesifikasi umum 2010 (revisi 3) pelaksanaa poyek jalan di Kabupaten Gianyar dengan menggunakan pendekatan secara kualiatatif. Selanjutnya mengumpulkan data dari hasil wawancara, dokumentasi, dan kuesioner maka untuk data tersebut akan diolah dengan Fisbone Diagram dan Root Cause Analysis (RCA), sehingga memperoleh kesimpulan. 


\subsection{Konsep Berfikir}

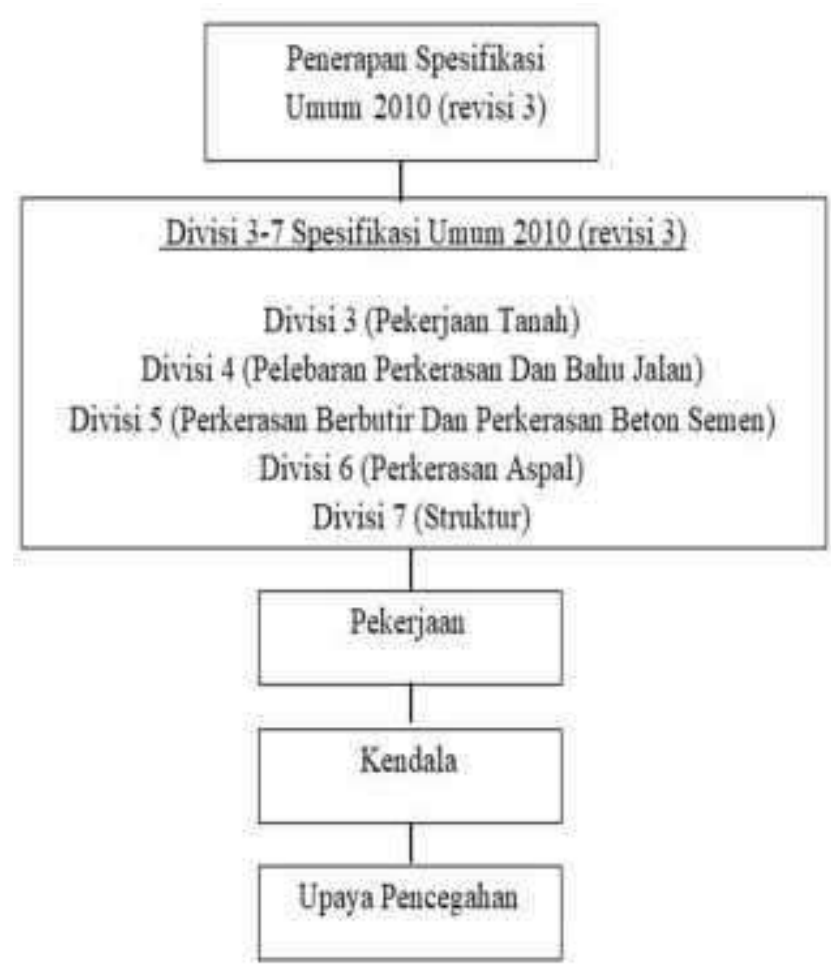

Gambar 2. Kerangka konsep

Berdasarkan kerangka berpikir diatas, maka dapat disusun suatu konsep penelitian yang kemudian menjadi kendala penerapan spesifikasi umum 2010 (revisi 3), dengan mencari oberservasi terhadap kendala apa saja yang terjadi dalam penerapanya, dampak yang diakibatkan, tindakan mitigasi atau penangan dalam pelaksanaan pekerjaan jalan dan kendala dari penerapan spesifikasi umum 2010 (revisi 3) sehingga dokumen spesifikasi umum pekerjaan konstruksi jalan dan jembatan ini dapat di evaluasi untuk ditindak lanjuti agar kedepanya tidak terjadi permasalahan yang dapat merugikan kedua belah pihak. Spesifikasi umum 2010 (revisi 3) merupakan bagian dari dokumen kontrak pekerjaan konstruksi jalan dan jembatan yang digunakan untuk mencapai suatu produk pekerjaan mulai dari proses persiapan, metode pelaksanaan, bahan, peralatan, pengendalian mutu, dan tata cara pembayaran. Penerapan spesifikasi ini dilakukan selama periode pelaksanaan pekerjaan konstruksi sebagai dasar penentuan pembayaran, hasil evaluasi yang diperoleh nanti menjadi suatu keberhasilan di dalam penerepannya, sehingga tidak menjadi temuan dan penyimpangan dalam proses penerapan dilapangan.

\section{KERANGKA DAN METODE PENELITIAN}

Penelitian tentang evaluasi kendala dalam penerapan sistem spesifikasi umum 2010 (revisi 3) pelaksanaa poyek jalan di Kabupaten Gianyar dengan menggunakan pendekatan secara kualiatatif. Setelah peneliti mengumpulkan data dalam bentuk hasil wawancara, dokumentasi, dan kuesioner maka untuk selanjutnya data tersebut akan dianalisis lebih mendalam lagi dengan Fisbone diagram dan Root Cause Analysis (RCA) sehingga membentuk suatu kesimpulan ilmiah-alamiah yang dapat diterima oleh berbagai kalangan. 


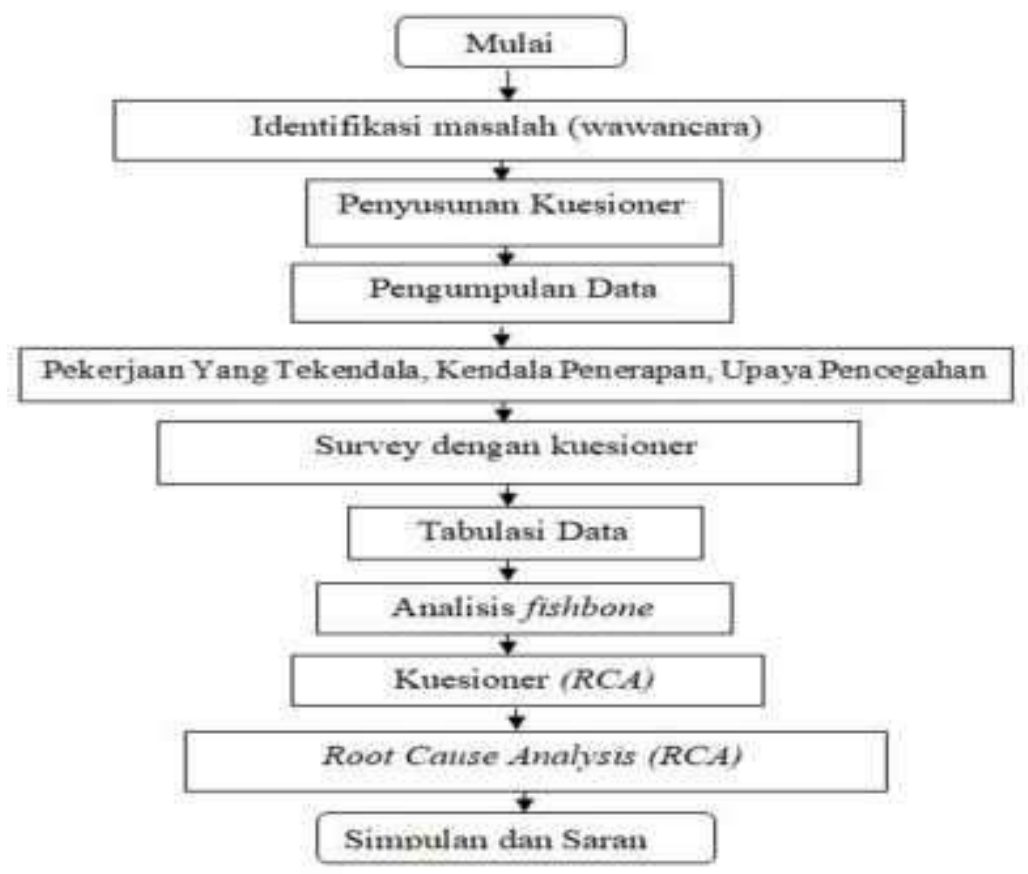

Gambar 3. Bagan rancangan alur penelitian

Pada teknik Non-Probability sampling terdapat Purposive sampling yang dikenal juga sampling pertimbangan ialah teknik sampling yang digunakan jika peneliti mempunyai pertimbangan-pertimbangan tertentu didalam pengambilan sampel atau penentuan jumlah sampel untuk tujuan tertentu (Anisah et al., 2013)

Teknik pengambilan data atau sampel pada penelitian ini dilakukan dengan metode purposive sampling yaitu metode pengambilan data yang sudah jelas tujuan sampelnya. Data yang diperoleh dari hasil penyebaran kuesioner, didalam kuesioner terdapat 3 pertanyaan untuk menjawab 3 rumusan masalah jenis pekerjaan, kendala dan upaya yang harus dilakukan untuk mencegah tidak tercapainya kualitas pada Spesifikasi Umum 2010 (revisi 3) pada pelaksanaan proyek jalan di Kabupaten Gianyar, untuk lingkup penyebaran kuesioner disebarkan dilingkungan kontraktor pelaksana, konsultan pengawas, dan staf di bagian Bina Marga Dinas Pekerjaan Umum dan Perumahan Rakyat Kabupaten Gianyar, berikut tabel responden :

Tabel 1. Tabel responden evaluasi penerapan kendalan Spesifikasi Umum 2010 (revisi 3)

\begin{tabular}{|c|l|r|l|l|}
\hline No & Responden & Jabatan & Pengalaman & Jumlah \\
\hline 1 & PT. SSA & $\begin{array}{c}\text { (1 Direktur Operasional, } 1 \\
\text { Site Manager, 7 Pelaksana } \\
\text { Lapangan) }\end{array}$ & (3-8 tahun) & orang \\
\hline 2 & PT. SJU & (2 Quantity Suveyor) & $(3-5$ tahun) & 2 orang \\
\hline 3 & PT. PAR & (2 Pelaksana Lapangan) & $(3,5-5$ tahun) & 2 orang \\
\hline 4 & PT. SB & (Quality Control) & 5 tahun & 1 orang \\
\hline 5 & PT. AM & (1 Site Manager) & 7 tahun & 1 orang \\
\hline 6 & PT. MTS & $\begin{array}{c}\text { (1 Kordinator Lapangan,1 } \\
\text { Staf teknis, 1 Insfector) }\end{array}$ & (5-8 tahun) & 3 orang \\
\hline 7 & CV. KWU & 1 Lapangan,1 Site Manager & $(3-5$ tahun) & 2 orang \\
\hline
\end{tabular}




\begin{tabular}{|c|c|c|c|c|}
\hline 8 & PUPR & (4 Staf Bina Marga) & 5 Tahun & 4 orang \\
\hline & Total & & & 24 orang \\
\hline
\end{tabular}

Kuesioner yang disebar menggunakan google form, dari 30 responden yang dikirimkan untuk mengisi kuesioner hanya 24 orang yang memberikan tanggapan, dari pihak kontraktor 17 orang, konsultan pengawas 3 orang, dan staf bina marga 4 orang. Posisi jabatan 8 orang pelaksana, site manager 3 orang, quantity surveyor 5 orang, direktur operasional 1 orang, coordinator lapangan 2 orang, insfektor 2 orang dan staf bina marga 4 orang, rata-rata responden memilki pengalaman pekerjaan 5-8 tahun yang dapat dikategorikan sebagai orang expert.

Menurut (Ardhana, 2002) bahwa analisis data adalah proses mengatur urutan data, mengorganisasikannya kedalam suatu pola, kategori, dan satuan uraian dasar. Pada penelitian ini, analisis yang digunakan adalah analisis sebab akibat atau fishbone analysis digunakan untuk menunjukan kendala penyebab permasalahan, mencari tahu akar permasalahan, mengidentifikasi dan menemukan kendala yang di hadapi dalam permasalahan penanggulangan dampak yang diakibatkan pada penerapan sistem spesifikasi umum 2010 (revisi 3) dengan brainstorming Root Cause Analysis (RCA).

Pengumpulan data dengan menggunakan metode deskriptif kualitatif dapat dilakukan dengan teknik wawancara (interview), angket (questionare), pengamatan (observation) serta focus Group discussion (FGD) (Nugrahani \& Hum, 2014)

\section{HASIL DAN PEMBAHASAN}

\subsection{Hasil Fisbone diagram dan Root Cause Analysis (RCA).}

Berdasarkan hasil Fisbone diagram dan Root Cause Analysis (RCA) terkait upaya penanganan kendala penerapan spesifikasi umum 2010 (revisi 3) dari 5 kategori yaitu material, metode kerja (method), cuaca dan lingkungan (environtment), tenaga pekerja (man) dan peralatan (equipment). Dari hasil kuesioner yang telah disebarkan jawaban responden mengenai kendala-kendala yang mempengaruhi penerepan spesifikasi umum 2010 (revisi 3) dimasukan di dalam 5 kategori tersebut.

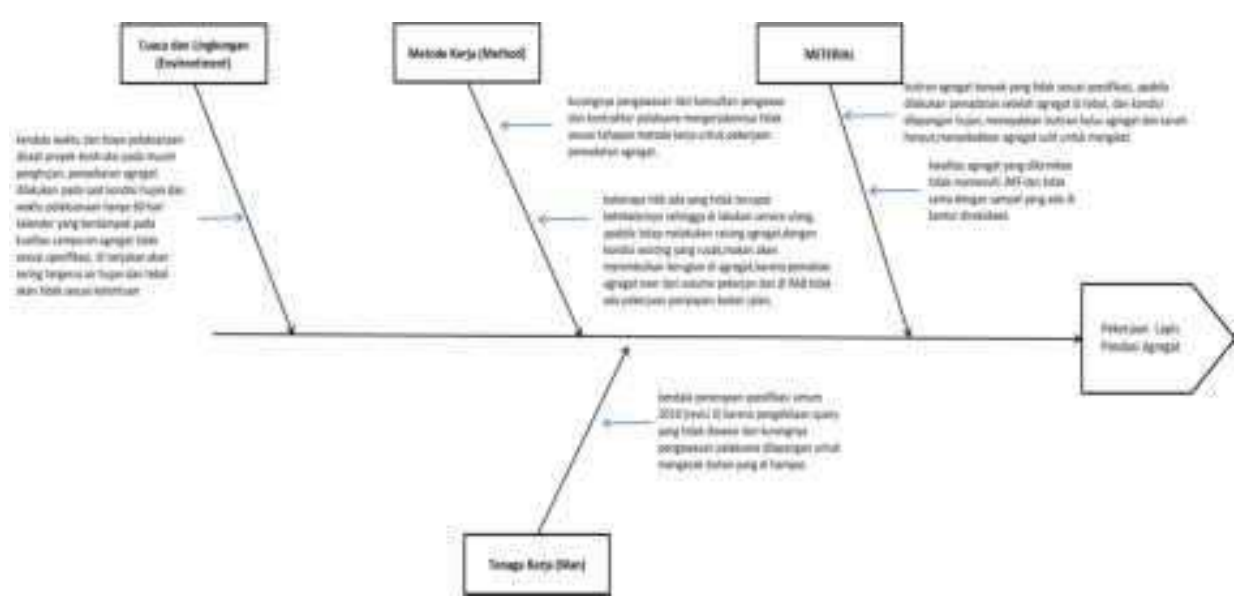

Gambar 4. Diagram fishbone akar masalah pekerjaan lapis pondasi agregat

Gambar 4 menunjukan kendala pekerjaan lapis pondasi agregat pada penerapan spesifikasi umum 2010 (revisi 3) disebabkan oleh :

1. Material :

- Butiran agregat tidak sesuai spesifikasi, menyebabkan agregat sulit untuk mengikat pada kondisi dipadatkan dengan air.

- Kualitas agregat yang dikirimkan tidak memenuhi JMF, atau tidak sama dengan contoh sampel yang ada.

2. Metode kerja (Method) : 
- Tidak ada pekerjaan penyiapan badan jalan, dibeberapa titik ketebalannya tidak tercapai sehingga dilakukan service ulang.

- Kurangnya pengawasan dari konsultan pengawas dan kontraktor pelaksana, pekerjaan tidak sesuai dengan tahapan metode kerja pemadatan agregat.

3. Cuaca dan Lingkungan (Environtment) :

- Kendala waktu pelaksanaan disaat musim hujan hanya 60 hari kalender yang berdampak pada kualitas pekerjaan karena terburu-buru dalam pengerjaanya.

4. Tenaga Kerja (Man) :

- Pengelolaan quary yang tidak diawasi dan kurangnya pengawasan pelaksana dilapangan untuk mengecek bahan yang diterima.

Berdasarkan hasil Root Cause Analysis (RCA) kendala bahan yang dikirim ke lapangan tidak sesuai spesifikasi, pengawas PU dan Konsultan menolak untuk menerima opnam agregat menjadi akar permasalahan diikuti dengan kendala kurang tegasnya team dari kotraktor untuk melakukan metode pekerjaan, banyaknya utilitas yang berada di bahu jalan,seperti pipa pdam dan pipa swadaya masyarakat, yang dapat menggangu pekerjaan galian pelebaran maupun pembuatan galian selokan dan drainase, galian pelebaran pemadatanya tidak maksimal karena dalam kondisi basah, dan hasil test sand cone tidak masuk, kordinasi kepada masyarakat maupun staf desa setempat yang membutuhkan waktu yang cukup lama untuk pemindahan pipa dan beberapa pemilik utilitas tidak melapor ke dinas PU untuk memasang utilitas yang menghambat pekerjaan galian sesuai dengan schedule, kurangnya pengawasan pada saat pencampuran bahan agregat di base camp maupun membeli dari supplier yang membuat campuran berbeda saat bahan sampai di lokasi proyek, kurang tegasnya pengawas dan kerjasama lapangan dari pihak kontraktor untuk memberitahu teamnya dalam metode kerja yang diterapkan dilapangan agar sesuai spesifikasi, dan kendala membawa alat molen yang susah ke lokasi pemasangan, dicampur secara manual dapat mengurangi spesifikasi atau tidak sesuai job mix formula.

\section{SIMPULAN DAN SARAN}

\subsection{Simpulan}

1. Pekerjaan yang sering mengalami kendala ketidasuaian dengan spesifikasi umum 2010 (revisi 3) didominasi pekerjaan galian lapis pondasi agregat $(95,83 \%)$ diikuti dengan pekerjaan galian dan campuran beraspal panas $(83,33 \%)$, pasangan batu $(75 \%)$, pekerjaan pelebaran dan perkerasan $(70,83 \%)$.

2. Kendala yang menyebabkan tidak tercapainya kualitas sesuai spesifikasi umum 2010 (revisi 3) proyek jalan di Kabupaten Gianyar adalah kendala pengiriman material ke lapangan tidak sesuai spesifikasi, pengawas PU dan Konsultan menolak untuk menerima opnam agregat yang menjadi akar permasalahan diikuti dengan kendala kurang tegasnya team dari kotraktor untuk melakukan metode pekerjaan, banyaknya utilitas yang berada di bahu jalan, seperti pipa pdam dan pipa swadaya masyarakat, yang dapat menggangu pekerjaan galian pelebaran maupun pembuatan galian selokan dan drainase, galian pelebaran pemadatanya tidak maksimal karena dalam kondisi basah, dan hasil test sand cone tidak masuk, kordinasi kepada masyarakat maupun staf desa setempat yang membutuhkan waktu yang cukup lama untuk pemindahan pipa dan beberapa pemilik utilitas tidak melapor ke dinas PU untuk memasang utilitas yang menghambat pekerjaan galian sesuai dengan schedule, kurangnya pengawasan pada saat pencampuran bahan agregat di base camp maupun membeli dari supplier yang membuat campuran berbeda saat bahan sampai di lokasi proyek, kurang tegasnya pengawas dan kerjasama lapangan dari pihak kontraktor untuk memberitahu teamnya dalam metode kerja yang diterapkan di lapangan agar sesuai spesifikasi, dan kendala membawa alat molen yang susah ke lokasi pemasangan, dicampur secara manual dapat mengurangi spesifikasi atau tidak sesuai job mix formula.

3. Upaya yang dapat dilakukan untuk mencegah tidak tercapainya kualitas pada penerapan Spesifikasi Umum 2010 (revisi 3) proyek jalan di Kabupaten Gianyar adalah lebih tegas kepada suplier dan base camp mengirim agregat sesuai JMF yang sudah disepakati, supaya tidak terjadi pengembalian agregat, kontraktor agar bekerja sesuai spesifikasi dan metode kerja agar mencapai mutu, harus di lakukan kordinasi dan kesepakatan antara pdam ,desa, dan kontraktor sebelum di lakukan galian,apabila terkena galian tidak meminta ganti rugi, mencari titik lain untuk di lakukan test sesuai dengan kondisi pelebaran yang sesuai speksifikasi, dan mengkordinasikan ke aparat Desa atau PDAM mengenai utilitas yang 
tertanam di badan jalan maupun bahu jalan, harus kordinasi atau bersurat kepada pihak terkait agar pipa-pipa yang terkena galian dipindahkan, konsultan pengawas dan pihak lab agar mengawasi pencampuran agregat sesuai spesifikasi, serta konsultan pengawas melaporkan ke pihak PU apabila tidak sesuai sampel yang di kirimkan akan di kembalikan, dari team kontraktor lebih kompak dalam bekerja supaya tidak terjadi miskomunikasi dilapangan anatara pelaksana dan team base camp, dan Tetap menggunakan metode kerja,pengawasan campuran ,supaya tidak mengurangi kualitas spesifikasi yang sudah ditentukan.

\subsection{Saran}

1. Pekerjaan yang sering mengalami kendala penerapan spesifikasi umum 2010 (revisi 3) disosialisasikan pada saat rapat PCM (Pre Construction Meeting) maupun rapat setiap bulan dan melakukan koordinasi untuk mendapatkan solusi dari setiap masalah.

2. Ketegasan kontraktor di harapkan benar-benar harus disiplin mengikuti metode kerja sesuai spesifikasi umum 2010 (revisi 3) supaya tidak terjadi kendala untuk mencapai kualitas yang diinginkan sesuai dengan umur rencana pekerjaan dan supaya tidak menjadi temuan.

3. Upaya pencegahan yang harus dilakukan untuk mencegah tidak tercapainya kualitas pada spesifikasi umum 2010 (revisi 3) dengan mengatur menajemen SDM dalam pengawasan dan kerjasama team.

\section{DAFTAR PUSTAKA}

Anisah, N., Riduwan, A., \& Amanah, L. (2013). Faktor-faktor yang mempengaruhi pertumbuhan deposito Mudharabah Bank Syariah. Jurnal Ilmu Dan Riset Akuntansi, 1(2), 169-186.

Ardhana, W. (2002). Konsep penelitian pengembangan dalam bidang pendidikan dan pembelajaran. Malang: Universitas Negeri Malang.

Armando, G. (2013). Pengaruh sistem pengendalian intern pemerintah dan pengawasan keuangan daerah terhadap nilai informasi laporan keuangan pemerintah (Studi Empiris pada SKPD di Kota Bukittinggi). Jurnal Akuntansi, 1(1).

Corcoran, P. B., \& Wals, A. E. J. (2004). Higher education and the challenge of sustainability. Dordrecht: Kluwer Academic Publishers, 10, 0-306.

Gao, F., Wang, Y., Shi, D., Zhang, J., Wang, M., Jing, X., Humphry-Baker, R., Wang, P., Zakeeruddin, S. M., \& Grätzel, M. (2008). Enhance the optical absorptivity of nanocrystalline TiO2 film with high molar extinction coefficient ruthenium sensitizers for high performance dye-sensitized solar cells. Journal of the American Chemical Society, 130(32), 10720-10728.

Ilie, G., \& Ciocoiu, C. N. (2010). Application of fishbone diagram to determine the risk of an event with multiple causes. Management Research and Practice, 2(1), 1-20.

Latino, M. A., Latino, R. J., \& Latino, K. C. (2019). Root cause analysis: improving performance for bottom-line results. CRC press.

Nugrahani, F., \& Hum, M. (2014). Metode penelitian kualitatif. Solo: Cakra Books.

Proboyo, B. (1999). Keterlambatan Waktu Pelaksanaan Proyek Klasifikasi dan Peringkat dari PenyebabPenyebabnya. Civil Engineering Dimension, 1(1), 46-58.

Soelistijo, A. (2018). PENINGKATAN MUTU PEMBANGUNAN JALAN MENGGUNAKAN SISTEM INFORMASI. Jurnal HPJI, 4(1), 1-10.

Sugiarto, D. S., Sunaryanto, L. T., \& Oetomo, D. S. (2003). Teknik sampling. Gramedia Pustaka Utama. Jakarta. 